\title{
Bioclimatic Conditions of June 2019 in Poland on a Multi-Year Background (1966-2019)
}

\author{
Arkadiusz Marek Tomczyk (D) \\ Department of Meteorology and Climatology, Adam Mickiewicz University, 61-712 Poznań, Poland; \\ atomczyk@amu.edu.pl; Tel.: +48-61-829-6266
}

\begin{abstract}
The study objective was to characterise human-biometeorological conditions in the summer season in the period 1966-2019 in Poland, with particular consideration of June 2019. The study was conducted based on data from the Institute of Meteorology and Water Management-National Research Institute (IMGW-PIB) for the years 1966-2019. The data provided the basis for the calculation of the Universal Thermal Climate Index (UTCI). The study revealed high spatial variability of human-biometeorological conditions in Poland, with strenuous character intensifying from the north to the south of the country. An increase in UTCI in the summer season was recorded in the studied multi-annual period. It was the most intensive in the north-eastern Poland. The consequence of the observed changes was an increase in the frequency of days with heat stress categories (days with UTCI $>26.0^{\circ} \mathrm{C}$ ), and a decrease in the frequency of days with cold stress categories (days with UTCI $<9.0^{\circ} \mathrm{C}$ ). Season 2019 stood out at the scale of the entire country in the context of the multi-annual period. This particularly concerns June, when mean monthly UTCI values were the highest in the analysed multi-annual period.
\end{abstract}

Keywords: UTCI; June; 2019; climate change; Poland

Citation: Tomczyk, A.M. Bioclimatic Conditions of June 2019 in Poland on a Multi-Year Background (1966-2019). Atmosphere 2021, 12, 1117. https:// doi.org/10.3390/atmos12091117

Academic Editor: Giridharan Renganathan

Received: 28 July 2021

Accepted: 28 August 2021

Published: 31 August 2021

Publisher's Note: MDPI stays neutral with regard to jurisdictional claims in published maps and institutional affiliations.

Copyright: (C) 2021 by the author. Licensee MDPI, Basel, Switzerland. This article is an open access article distributed under the terms and conditions of the Creative Commons Attribution (CC BY) license (https:// creativecommons.org/licenses/by/ $4.0 /)$.

\section{Introduction}

The warming progressing over the last several decades has intensified in recent years [1,2]. Global mean surface temperature in the years $2011-2020$ was higher by $1.09{ }^{\circ} \mathrm{C}$ than the mean value from the period 1850-1900 [2]. According to NOAA [3], in the years $1880-2019$ at the global scale, 9 out of 10 warmest years were those after 2000. The warmest year was 2016, and in Europe 2018. The extreme character of 2018 was also pointed out by Hoy et al. [4], analysing thermal extremes in Europe; Tomczyk and Bednorz [5], analysing thermal conditions in Poland; as well as Zahradníček et al. [6], investigating changes in air temperature in the Czech Republic in recent decades.

The second hottest year in terms of mean air temperature, both at the global scale and in Europe, was 2019 [3]. That year was particularly characterised by high air temperature values in June [7-9]. As evidenced by Sulikowska and Wypych [8], citing local meteorological services, record-breaking values of the maximum air temperature in June were recorded in many places, e.g., in Spain $\left(43.4{ }^{\circ} \mathrm{C}\right.$ in Lleida), Germany $\left(39.6{ }^{\circ} \mathrm{C}\right.$ in Bernburg/Saale), Poland $\left(38.2{ }^{\circ} \mathrm{C}\right.$ in Radzyn), and the Czech Republic $\left(38.9{ }^{\circ} \mathrm{C}\right.$ in Doksany). All-time temperature record $\left(45.9^{\circ} \mathrm{C}\right)$ for any single station was broken in France on 28 June in Gallargues-le-Montueux near the city of Nîmes [7]. The highest monthly air temperature anomalies were determined in central Europe, where over a considerable area they exceeded $6.0^{\circ} \mathrm{C}$, and in eastern Germany and western Poland even $8.0^{\circ} \mathrm{C}$ [8].

The year 2019 also stood out in terms of the number of heat waves in June and July, particularly in central Europe [10,11]. As evidenced by the authors of the cited paper, two of the strongest heat waves were recorded at the ends of June and July, with the greatest temperature anomaly of approximately $8.9^{\circ} \mathrm{C}$. In June, the highest number of hot days was recorded in the Baltic region, where these days constituted more than half 
of days in the month $[8,9]$. In recent years, during many summer seasons, intensive heat waves occurred, e.g., in 2003 and 2006, in southern and western Europe [12-15], in 2010 in eastern Europe [16,17], and in 2015 in central Europe [18-20]. The heat wave from 2003 was particularly exceptional in the modern history of Europe due to its tragic social and economic effects. It is estimated that the total number of additional deaths caused by human-biometeorological stress of the human in 12 European countries exceeded 80,000, including more than 45,000 in August alone [21].

The assessment of the strenuous character of atmospheric conditions from the human point of view adopts different human-biometeorological indices, considering the effect of not only air temperature, but also other meteorological parameters such as wind speed, air humidity, etc. [22-25]. This type of indices has been frequently applied in the general assessment of human-biometeorological conditions or assessment of extreme situations at various spatial scales and in different climatic zones [26-31]. In recent years, studies from Poland have involved the analysis of human-biometeorological conditions occurring during selected heat waves [32,33]. In the first of the cited papers, based on the Universal Thermal Climate Index (UTCI), the authors characterised conditions during the wave from 2015. In the second paper, the analysis covered conditions during waves from 1994 and 2015 based on the Physiologically Equivalent Temperature (PET) index. Both waves are included to the most intensive heat waves in Poland in recent decades [19,34,35]. According to Tomczyk et al. [33], meteorological conditions were similar in the case of both waves, although they were more strenuous during the heat wave from 1994.

Considering the fact that current research of the summer season 2019 primarily focused on thermal conditions, it is justified to analyse comprehensive atmospheric conditions affecting the human. Research based on selected human-biometeorological indices fully meets this condition. The obtained results present the scope of possible humanbiometeorological conditions in Poland at the beginning of summer. It may be helpful in the development of a relevant social warning system. Due to the serious threat to human health and life related to the occurrence of extreme human-biometeorological conditions, and high social and economic costs of their effects, the presented results can be interesting for a broad and diverse group of recipients. Due to the above, the study objective was to characterise human-biometeorological conditions in the summer season in the years 1966-2019, with particular consideration of June 2019. Moreover, an important aspect of the conducted research was the determination of the circulation conditions of occurrence of human-biometeorological conditions in June 2019. The analysis permitted the determination of the dissimilarity of the baric conditions in the analysed month in reference to the entire multi-annual period.

The article is organised as follows. Section 2 describes the used source data and the applied index, as well as the conducted analyses. Section 3 presents study results in the following order: UTCI characteristics in summer in the period 1966-2019 and in summer 2019, UTCI characteristics in June in the years 1966-2019 and in June 2019, as well as the characteristics of the circulation conditions. Section 4 sums up the study results and refers the obtained results to other research. The last chapter presents the conclusions.

\section{Data and Methods}

The study was based on daily data from the period June-August in the years 1966-2019 from 30 stations in Poland (Figure 1). It employed data series from 12:00 UTC such as air temperature $\left({ }^{\circ} \mathrm{C}\right)$, relative humidity $(\%)$, wind speed $\left(\mathrm{m} \cdot \mathrm{s}^{-1}\right)$, and total cloudiness (oct.). This time of day corresponds to most types of outdoor human activity in Poland [36]. Data from that time had been commonly applied in earlier studies for the assessment of the human-biometeorological situation for a given day [26,30]. All the data series were homogenous and were obtained from the certified data base of the Institute of Meteorology and Water Management-National Research Institute (IMGW-PIB). The data meet the requirements in terms of good quality. 


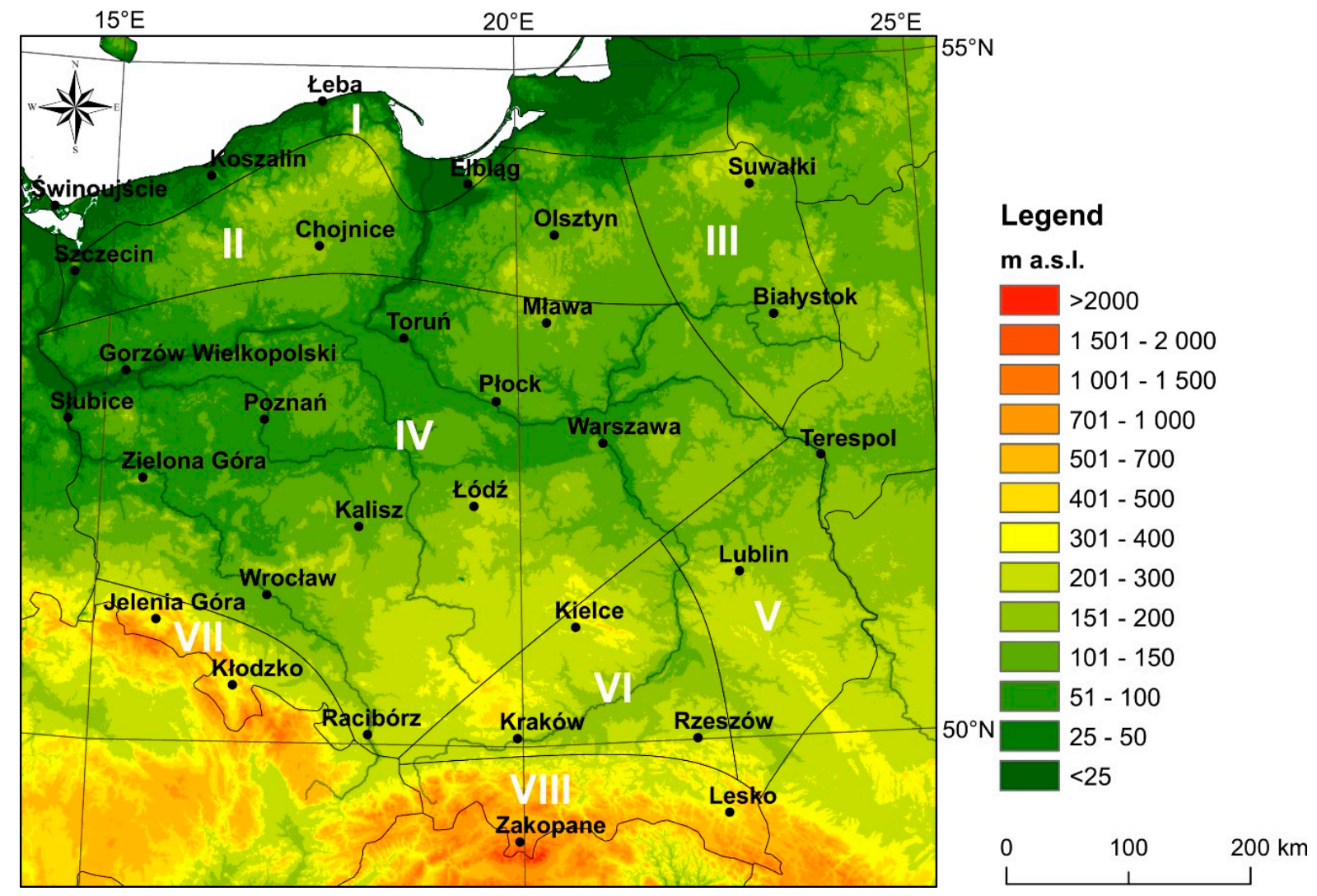

Figure 1. Location of meteorological stations and their locations in bioclimatic regions of Poland (I-Coastal, II—Lakeland, III—North-East, IV—Central, V—South-East, VI—Upland, VII—Sudetic, VIII—Carpathians; according to Błażejczyk [37]).

The aforementioned data were used for the calculation of the Universal Thermal Climate Index. UTCI is defined as equivalent air temperature at which in reference conditions the basic physiological parameters of the organism would adopt the same values as in the actual conditions. It is assumed that heat exchange between the human body and the surroundings depends only on air temperature, with a constant level of the remaining meteorological parameters [24]. It is a unidimensional value reflecting the response of the organism to multidimensionally described meteorological and physiological information $[25,38]$. UTCI values are a measure of heat stress of the organism and are expressed in ${ }^{\circ} \mathrm{C}[24]$.

UTCI is based on the Fiala multinode model of human heat transfer and temperature regulation [38-40]. It is divided into two subsystems of heat exchange and temperature regulation: passive and active. The former one considers the physical elements of heat transfer within the organism and on its surface. The latter considers the physiological mechanisms of temperature regulation that change the heat stream value. An important element in the calculation of UTCI is mean radiant temperature (Tmrt), denoting the temperature of the thin layer of air surrounding the human body. It develops due to the streams of solar and long-wave radiation reaching the human body. Because measurements of solar and long-wave radiation streams are rare, the determination of the value of Tmrt sometimes requires the application of indirect methods of assessment of radiation streams, as is the case in the procedures implemented in programme BioKlima 2.6. [24]. The programme permitted the calculation of UTCI values [41,42].

UTCI values (from 12:00 UTC) provided the basis for mean index values for summer (June-August) and summer months in the period 1966-2019. Then, the occurrence of particular UTCI classes was determined (Table 1). In the first part, the analysis covered average human-biometeorological conditions in summer in the study period and in summer 2019. In the second part, the analysis concerned conditions in June, both in the multi-annual 
period and in 2019. Moreover, UTCI anomalies were calculated. The anomalies were calculated as the difference between UTCI value on a given day and its mean value on a given day in the multi-annual period 1966-2019.

Table 1. Scale of assessment of heat stress of the organism according to the UTCI index [24].

\begin{tabular}{cccc}
\hline UTCI $\left({ }^{\circ} \mathbf{C}\right)$ & Stress Category & UTCI $\left({ }^{\circ} \mathbf{C}\right)$ & Stress Category \\
\hline above +46 & Extreme heat stress & +9 to 0 & Slight cold stress \\
\hline+38 to +46 & $\begin{array}{c}\text { Very strong heat } \\
\text { stress }\end{array}$ & 0 to -13 & Moderate cold stress \\
\hline+32 to +38 & Strong heat stress & -13 to -27 & Strong cold stress \\
\hline+26 to +32 & Moderate heat stress & -27 to -40 & $\begin{array}{c}\text { Very strong cold } \\
\text { stress }\end{array}$ \\
\hline+9 to +26 & No thermal stress & below -40 & Extreme cold stress \\
\hline
\end{tabular}

Circulation conditions in June 2019 were also analysed in order to explain the conditions of the occurring human-biometeorological situation. For this purpose, the following maps were prepared: sea level pressure (SLP) and isobaric height of $500 \mathrm{hPa}(\mathrm{z} 500 \mathrm{hPa})$. Maps of SLP and z500 hPa were additionally prepared, as well as maps of temperature anomalies at an isobaric level of $850 \mathrm{hPa}$ (T850). Anomalies were calculated as the difference between the average value of each of the aforementioned elements on a particular day and its average value on a given day in the analysed multi-annual period (1966-2019). After general description of circulation conditions, detailed baric situations were designated. The designation was performed through grouping particular days by SLP values, with the application of the minimum variance method known as the Ward's method [43]. A detailed description of the applied method is included in earlier publications [30]. The above analyses were performed based on daily sea level pressure values, height of isobaric surface of $500 \mathrm{hPa}$, and air temperature at the isobaric surface of $850 \mathrm{hPa}$. The data were obtained from the collection of the National Center for Environmental Prediction/National Center for Atmospheric Research (NCEP/NCAR) Reanalysis [44] available in the archives of NOAA ESRL PSD (Earth System Research Laboratory Physical Science Division).

Moreover, circulation conditions were also described based on the Grosswetterlagen circulation calendar (GWL) (Table 2) developed by Hesse and Brezowsky [45]. Circulation types for particular days were obtained from two sources: for the period 1966-2009 from the Potsdam Institute for Climate Impact Research, and for the years 2010-2019 from Deutscher Wetterdienst. The data provided the basis for the determination of the frequency of occurrence of particular types in June in the analysed multi-annual period and in 2019.

Table 2. Types of Grosswetterlagen circulation [45].

\begin{tabular}{ccc}
\hline Grosswettertype (GWT) & Symbol & Grosswetterlage (GWL) \\
\hline \multirow{2}{*}{ West } & WA & West Circulation, anticyclonal \\
& WZ & West Circulation, cyclonal \\
& WS & Southern West Circulation \\
& WW & Angled West Circulation \\
\hline \multirow{2}{*}{ Southwest } & SWA & Southwest Circulation, anticyclonal \\
& SWZ & Southwest Circulation, cyclonal \\
\hline \multirow{2}{*}{ Northwest } & NWA & Northwest Circulation, anticyclonal \\
& NWZ & Northwest Circulation, cyclonal \\
\hline \multirow{2}{*}{ Central Europe High } & HM & Central European High \\
& BM & Central European Ridge \\
\hline \multirow{2}{*}{ Central Europe Low } & TM & Central European Low \\
\hline
\end{tabular}


Table 2. Cont.

\begin{tabular}{ccc}
\hline Grosswettertype (GWT) & Symbol & Grosswetterlage (GWL) \\
\hline \multirow{4}{*}{ North } & NA & North Circulation, anticyclonal \\
& NZ & North Circulation, cyclonal \\
& HNA & Norwegian Sea High, anticyclonal \\
& HNZ & Norwegian Sea High, cyclonal \\
& HB & British Isles High \\
& TRM & Central Europe Trough \\
\hline \multirow{2}{*}{ Northeast } & NEA & Northeast Circulation, anticyclonal \\
& NEZ & Northeast Circulation, cyclonal \\
\hline \multirow{3}{*}{ East } & HFA & Fennoscandian High, anticyclonal \\
& HFZ & Fennoscandian High, cyclonal \\
& HNFA & Norwegian Sea/Fennoscandia High, \\
& HNFZ & anticyclonal \\
& SEA & Norwegian Sea/Fennoscandia High, cyclonal \\
\hline \multirow{2}{*}{ Southeast } & SEZ & Southeast Circulation, anticyclonal \\
& SA & Southeast Circulation, cyclonal \\
\hline \multirow{2}{*}{ South } & SZ & South Circulation, anticyclonal \\
& TB & South Circulation, cyclonal \\
& TRW & British Isles Low \\
& U & Western Europe Trough \\
\hline
\end{tabular}

\section{Results}

3.1. UTCI in the Summer Season in the Years 1966-2019 and 2019

In the summer season in the period 1966-2019, the mean UTCI value in Poland was $20.5^{\circ} \mathrm{C}$. The lowest index values were recorded in the north of the country, in the eastern part of the coast with a minimum in Łeba $\left(16.0^{\circ} \mathrm{C}\right)$ (Figure 2a). An increase in UTCI values occurred towards the south and east, and the highest values were determined in the upper course of the Oder River with a maximum in Raciborz $\left(22.7^{\circ} \mathrm{C}\right)$. The above data suggest that the human-biometeorological conditions caused no thermal stress, although their strenuous character increased from the north to the south of the country. High variability of UTCI from season to season was determined in the studied multi-annual period (Figure 3). For the entire area, the lowest mean UTCI value was recorded in summer $1980\left(16.5^{\circ} \mathrm{C}\right)$. Over a considerable area (in 14 stations), it was a season with the lowest mean UTCI in the analysed period, and its values in that season varied from $13.5^{\circ} \mathrm{C}$ in Suwałki to $19.1{ }^{\circ} \mathrm{C}$ in Raciborz. In the remaining stations, the lowest UTCI was recorded in the following seasons: 1987 (four stations), 1978 (four stations), 1974 (three stations), 1993 (three stations), 1985 (one station), and 1998 (one station). The highest mean UTCI value calculated for the entire area was determined for summer 2019 , reaching $24.3^{\circ} \mathrm{C}$. The season with the highest number of stations that recorded the highest index value in the study period was summer 1992 (12 stations). During that summer, mean UTCI varied from $18.0^{\circ} \mathrm{C}$ in Łeba to $27.2^{\circ} \mathrm{C}$ in Raciborz. Values higher than $26.0^{\circ} \mathrm{C}$ were also recorded in Kraków, i.e., in these stations, mean conditions in summer exceeded the threshold of the heat stress category. In the analysed multi-annual period, UTCI values increased throughout the area. It was statistically significant in $87 \%$ of stations. The most intensive increase was observed in north-eastern Poland, in Suwałki, reaching $1.06{ }^{\circ} \mathrm{C} / 10$ years (Figure 3, Table 3). The above data point to an increase in the strenuous character of human-biometeorological conditions in the summer season in Poland. 

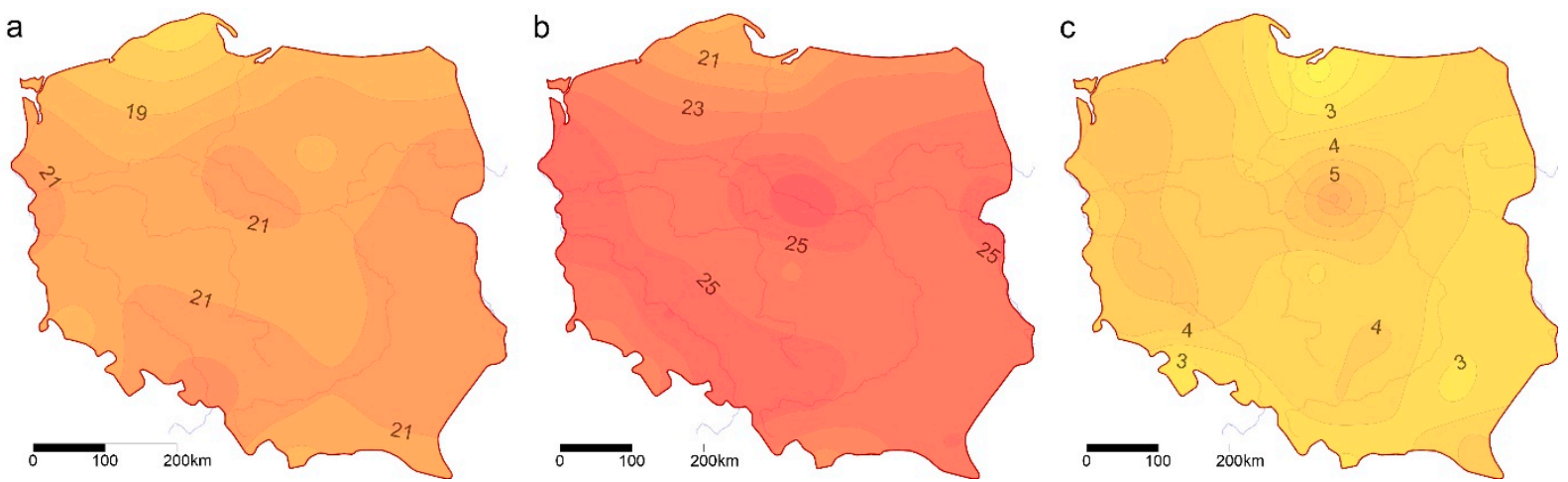

Figure 2. Mean UTCI in the summer season in the years 1966-2019 (a), mean UTCI in summer 2019 (b), and anomalies (c).
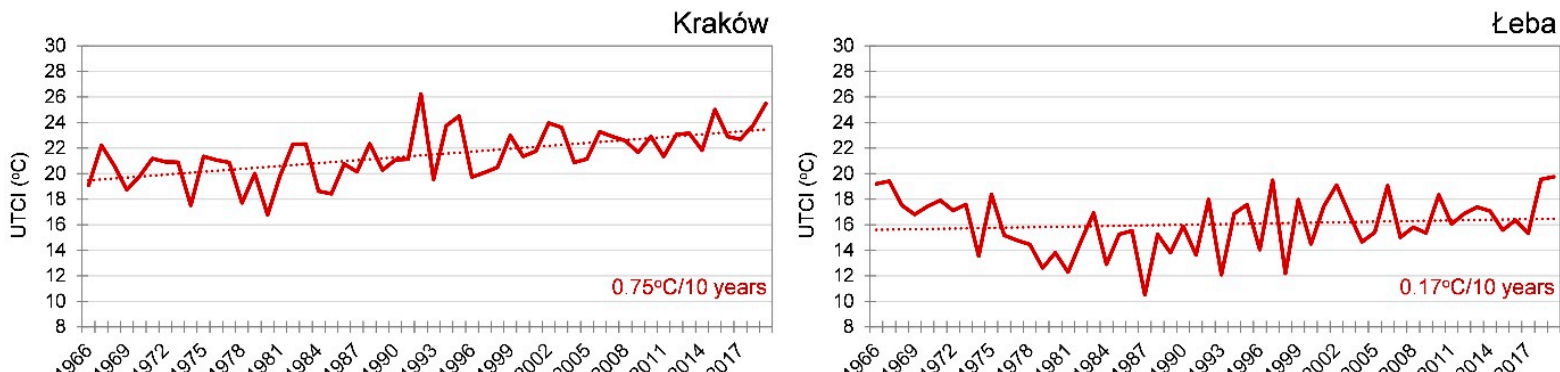

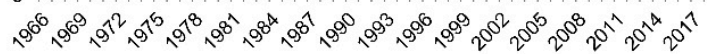

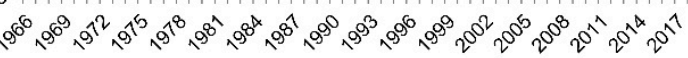
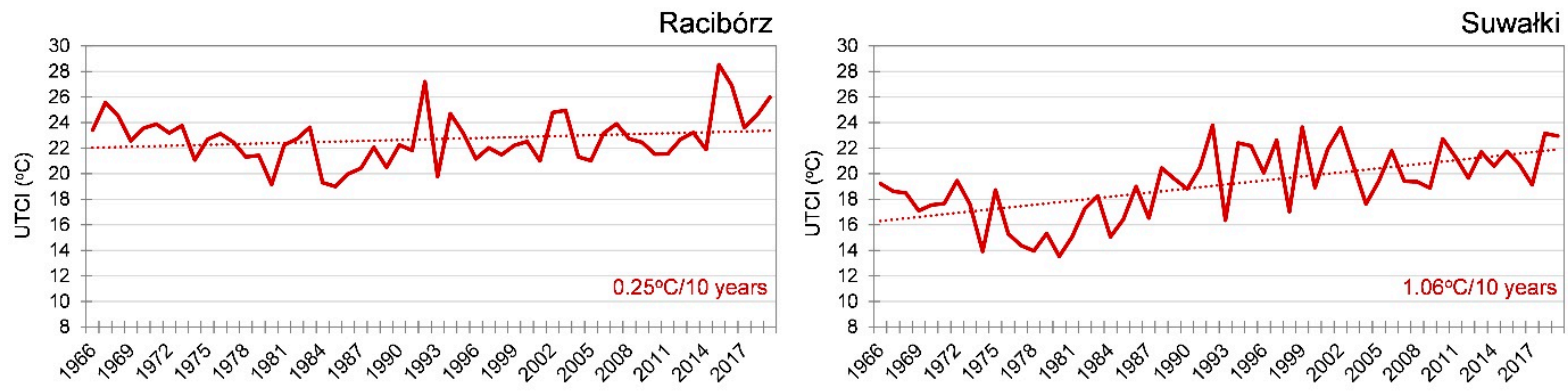

Figure 3. Multi-annual course of mean UTCI in summer in the years 1966-2019 in selected stations.

Table 3. Changes of UTCI in summer and June in the years 1966-2019. Stations are arranged in spatial order from the north to the south.

\begin{tabular}{ccccccc}
\hline \multirow{2}{*}{ Station } & \multicolumn{2}{c}{ Changes $\left[{ }^{\circ} \mathbf{C} / \mathbf{1 0}\right.$ Years $]$} & \multirow{2}{*}{ Station } & \multicolumn{2}{c}{ Changes ${ }^{\circ} \mathrm{C} / \mathbf{1 0}$ Years $]$} \\
\cline { 2 - 3 } & Summer & June & & Summer & June \\
\hline Łeba & 0.17 & 0.19 & & Warszawa & $\mathbf{0 . 8 1}$ & $\mathbf{0 . 7 5}$ \\
\hline Koszalin & $\mathbf{0 . 4 6}$ & 0.33 & Terespol & $\mathbf{0 . 7 4}$ & $\mathbf{0 . 6 1}$ \\
\hline Elbląg & 0.22 & 0.19 & Zielona Góra & $\mathbf{0 . 6 0}$ & $\mathbf{0 . 5 9}$ \\
\hline Suwałki & $\mathbf{1 . 0 6}$ & $\mathbf{0 . 8 2}$ & Kalisz & 0.20 & 0.13 \\
\hline Świnoujście & $\mathbf{0 . 9 8}$ & $\mathbf{0 . 9 3}$ & Eódź & $\mathbf{0 . 6 6}$ & $\mathbf{0 . 6 7}$ \\
\hline Olsztyn & $\mathbf{0 . 4 0}$ & 0.24 & Lublin & $\mathbf{0 . 6 8}$ & $\mathbf{0 . 6 8}$ \\
\hline Chojnice & $\mathbf{0 . 5 0}$ & 0.42 & Wrocław & $\mathbf{0 . 4 9}$ & $\mathbf{0 . 4 2}$ \\
\hline Szczecin & $\mathbf{0 . 4 9}$ & 0.42 & Jelenia Góra & $\mathbf{0 . 6 4}$ & $\mathbf{0 . 5 8}$ \\
\hline Białystok & $\mathbf{0 . 6 4}$ & $\mathbf{0 . 4 8}$ & Kielce & $\mathbf{0 . 5 1}$ & $\mathbf{0 . 5 5}$ \\
\hline Mława & $\mathbf{0 . 9 5}$ & $\mathbf{0 . 9 1}$ & Kłodzko & $\mathbf{0 . 4 2}$ & $\mathbf{0 . 4 5}$ \\
\hline
\end{tabular}


Table 3. Cont.

\begin{tabular}{ccccccc}
\hline \multirow{2}{*}{ Station } & \multicolumn{2}{c}{ Changes $\left[{ }^{\circ} \mathrm{C} / \mathbf{1 0}\right.$ Years $]$} & \multirow{2}{*}{ Station } & \multicolumn{2}{c}{ Changes $\left[{ }^{\circ} \mathrm{C} / \mathbf{1 0}\right.$ Years $]$} \\
\cline { 2 - 3 } & Summer & June & & Summer & June \\
\hline Toruń & $\mathbf{0 . 6 1}$ & $\mathbf{0 . 5 6}$ & & Rzeszów & $\mathbf{0 . 6 9}$ & $\mathbf{0 . 6 6}$ \\
\hline $\begin{array}{c}\text { Gorzów } \\
\text { Wielkopolski }\end{array}$ & $\mathbf{0 . 6 0}$ & $\mathbf{0 . 6 1}$ & & Kraków & $\mathbf{0 . 7 5}$ & $\mathbf{0 . 7 9}$ \\
\hline Płock & $\mathbf{0 . 6 9}$ & $\mathbf{0 . 6 0}$ & Racibórz & 0.25 & 0.15 \\
\hline Poznań & $\mathbf{0 . 7 6}$ & $\mathbf{0 . 6 4}$ & Lesko & $\mathbf{0 . 9 6}$ & $\mathbf{0 . 9 6}$ \\
\hline Słubice & $\mathbf{0 . 5 2}$ & $\mathbf{0 . 5 7}$ & Zakopane & $\mathbf{0 . 6 5}$ & $\mathbf{0 . 6 6}$ \\
\hline bold— $-p<0.05$. & & &
\end{tabular}

The study showed that in all stations in the analysed period, the highest mean monthly UTCI values were recorded in August. In particular stations, the index values varied from $17.7^{\circ} \mathrm{C}$ in Łeba to $23.8^{\circ} \mathrm{C}$ in Raciborz. Moreover, in four stations, the same mean value as in August was also recorded in July. Differences in mean UTCI between July and August were inconsiderable and did not exceed $0.6{ }^{\circ} \mathrm{C}$. Substantially lower UTCI values were determined in June.

As mentioned above, at the scale of the entire country, the highest mean UTCI value was determined for summer 2019. During that season, like on average in the multiannual period, an increase in UTCI occurred from the north towards the centre of country (Figure 2b). The lowest index values were recorded at the coast, in Łeba $19.8^{\circ} \mathrm{C}$. Among areas with the highest UTCI values, the regions of central Poland and south-western regions along the Oder River valley stand out. The highest mean seasonal index value was $27.7^{\circ} \mathrm{C}$, recorded in Płock. More than $26.0^{\circ} \mathrm{C}$ was also observed in Wrocław, and in these stations, the season was classified as a season with heat stress. In the study area, in this season UTCI was higher than on average in the analysed period (1966-2019). The highest deviations from average values were determined in the central and western part of the country. In particular stations, anomalies varied from $1.7^{\circ} \mathrm{C}$ in Elblag to $6.2^{\circ} \mathrm{C}$ in Płock (Figure 2c).

In 2019, the course of mean UTCI values in summer deviated from the average conditions in the analysed period. Among summer months, in $97 \%$ of stations, the highest mean monthly UTCI value was recorded in June. In that month, the index value varied from $22.0^{\circ} \mathrm{C}$ to $29.5^{\circ} \mathrm{C}$ in Płock. In as many as $77 \%$ of stations, the threshold of $26.0^{\circ} \mathrm{C}$ was exceeded, i.e., the threshold of heat stress. Lower UTCI values were recorded in the remaining months of the summer season, and in $97 \%$ of stations the lowest in July.

Over the entire study area, on average in the summer season, conditions causing no thermal stress were observed the most frequently (Figure 4a). The highest share of such conditions was recorded in the north of the country, along the coast, as well as in south-eastern regions. In particular stations, the share of this category of heat stress ranged from $56 \%$ in Raciborz to $76 \%$ in Zakopane. More than 70\% was also recorded in Świnoujście, Łeba, Elblag, and Koszalin. UTCI above $26.0^{\circ} \mathrm{C}$, i.e., moderate, strong, and very strong heat stress, was most frequently recorded in the upper course of the Oder River and in central Poland. The frequency of these categories decreased towards the north and south, and together with an increase in height above sea level. The contribution of days with UTCI exceeding $26.0{ }^{\circ} \mathrm{C}$ varied from $9 \%$ in Łeba to $39 \%$ in Raciborz. More than 30\% was also observed in Rzeszów, Kraków, Wrocław, Słubice, Płock, Terespol, Lublin, Warszawa, and Białystok. UTCI below $9.0^{\circ} \mathrm{C}$ was recorded the most seldom. It corresponds with slight, moderate, and strong cold stress. These categories were observed the most frequently in northern and north-eastern Poland. In particular stations, the share of the analysed days varied from $4 \%$ in Torun to $18 \%$ in Łeba. In the studied multiannual period, intensification of positive heat stress was observed. Except for two stations that showed no changes, the number of days with UTCI above $26.0^{\circ} \mathrm{C}$ increased. In $57 \%$ of stations, the recorded changes were statistically significant. The most intensive 
changes were particularly determined in eastern and central regions of the country, and the highest increase was recorded in Lesko and Suwałki (3.33 days/10 years). The number of days with UTCI below $9.0^{\circ} \mathrm{C}$ simultaneously decreased (apart from one station, where no changes were recorded). In $87 \%$ of stations, the recorded changes were statistically significant, and their greatest rate occurred in Mława ( -2.63 days/10 years), and Suwałki ( -2.17 days $/ 10$ years).
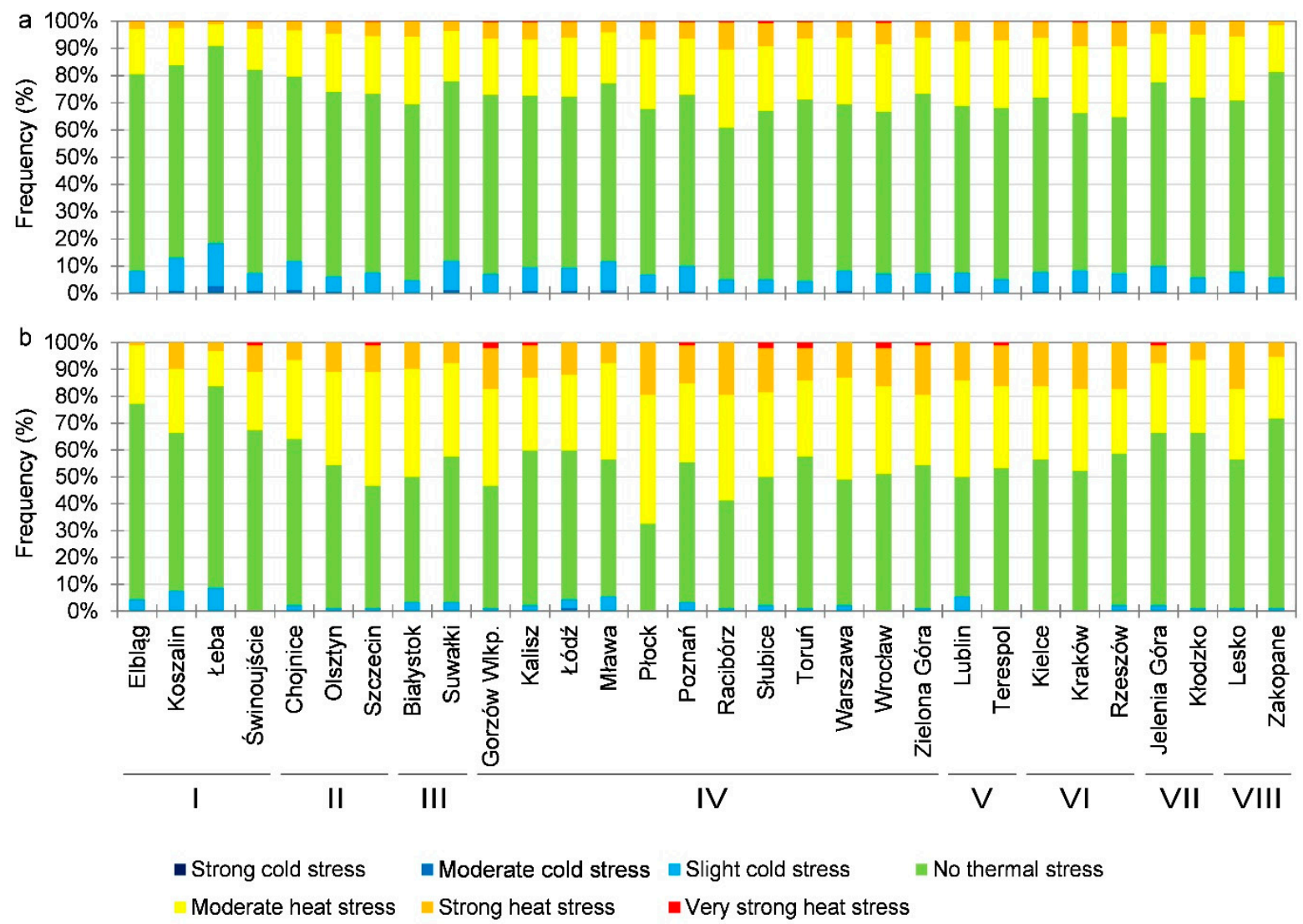

Figure 4. Frequency of occurrence of particular categories of heat stress in the summer season in the period 1966-2019 (a) and 2019 (b).

Conditions different than average were observed in summer 2019 (Figure $4 \mathrm{~b}$ ). In a large majority of stations (93\%), fewer days with conditions of no thermal stress were recorded. The greatest differences were determined in Płock, Gorzów Wielkopolski, and Szczecin, where they exceeded $20 \%$. In $73 \%$ of stations, such days constituted more than half of days of the summer season. Their smallest share was recorded in the central regions of the country and in the upper course of the Oder River, and largest at the coast and in the south of the country with an increase in height. In particular stations, the share of days with no thermal stress varied from 33\% in Płock to $75 \%$ in Łeba. Over the entire area, more days with UTCI above $26.0^{\circ} \mathrm{C}$ were recorded, and the greatest deviations from average conditions (more than 20\%) were observed in Płock, Szczecin, Gorzów Wielkopolski, Mława, Warszawa, and Suwałki. The spatial distribution of frequency of such days was opposite to the frequency of days with no thermal stress. In $17 \%$ of stations, days above this category constituted more than half of days of the summer season. The lowest frequency of such days was recorded in Łeba (16\%), and highest in Płock (67\%). Days with UTCI below $9.0^{\circ} \mathrm{C}$ were recorded considerably more seldom. Over a major area, they constituted not more than $3 \%$ of days of the season, and in six stations they were not recorded (Kielce, Kraków, Płock, Świnoujście, Terespol, Wrocław). Their higher frequency occurred at the coast (Łeba 9\%). 


\subsection{UTCI in June in the Years 1966-2019 and 2019}

In June in the period 1966-2019, the mean UTCI value in Poland was $18.6{ }^{\circ} \mathrm{C}$. An increase in the index value occurred from the north to the south and east of the country (Figure 5a). The lowest values were recorded at the coast (in Łeba $13.3^{\circ} \mathrm{C}$ ), and highest in the upper course of the Oder River (in Raciborz $20.9^{\circ} \mathrm{C}$ ). More than $20^{\circ} \mathrm{C}$ was also recorded in Rzeszów, Słubice, Terespol, and Białystok. In the analysed multi-annual period, UTCI increased in June. In $70 \%$ of stations, the increase was statistically significant. The greatest rate of changes was recorded in Lesko $\left(0.96{ }^{\circ} \mathrm{C} / 10\right.$ years $)$, Świnoujście $\left(0.93^{\circ} \mathrm{C} / 10\right.$ years $)$, and Mława $\left(0.91{ }^{\circ} \mathrm{C} / 10\right.$ years) (Figure 6, Table 3).
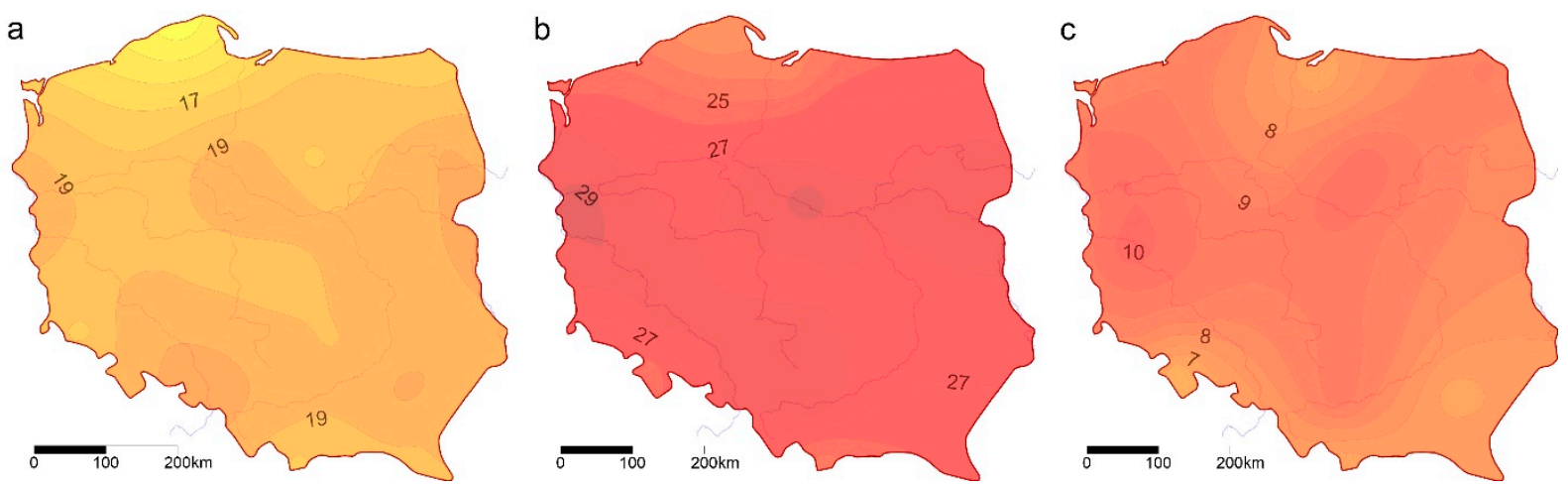

Figure 5. Mean UTCI in June in the years 1966-2019 (a), mean UTCI in June 2019 (b), and anomalies (c).
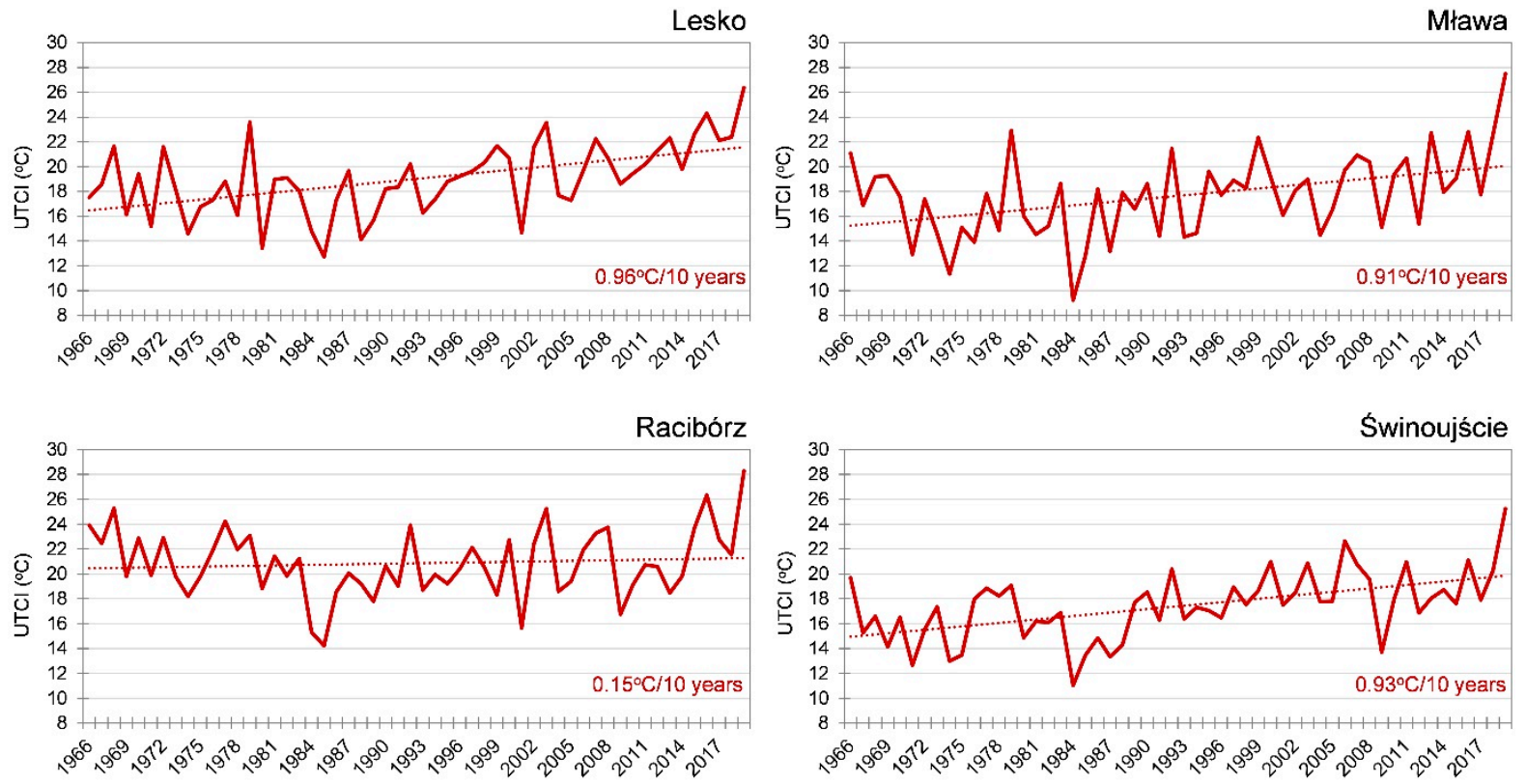

Figure 6. Multi-annual course of mean UTCI in June in the years 1966-2019 in selected stations.

In $97 \%$ of stations, the lowest mean monthly UTCI was recorded in the first two decades of the analysed period. At the scale of the entire country, the lowest mean value was observed in $1984\left(13.2^{\circ} \mathrm{C}\right)$ and $1985\left(13.8^{\circ} \mathrm{C}\right)$. Both in the former and latter season, 11 stations with the lowest UTCI in the study period were recorded. In particular stations, mean index values varied from $8.1^{\circ} \mathrm{C}$ in Łeba to $17.5^{\circ} \mathrm{C}$ in Terespol in 1984, and from $11.2^{\circ} \mathrm{C}$ in Łeba to $17.5^{\circ} \mathrm{C}$ in Białystok in 1985 .

Over the entire area, the highest mean UTCI values for June were recorded in 2019. Like for the multi-annual period, they increased from the north (Figure $5 b$ ). The highest mean UTCI were recorded in central regions of the country and along the Oder River. Over the major area, mean UTCI exceeded $26.0^{\circ} \mathrm{C}$, i.e., the threshold of moderate heat stress. 
The highest value was determined in Płock $\left(29.5^{\circ} \mathrm{C}\right)$ and Słubice $\left(29.2^{\circ} \mathrm{C}\right)$. Values recorded in that year were considerably higher than average in the analysed period, particularly in the central and western regions of the country. In particular stations, UTCI anomalies varied from $6.2{ }^{\circ} \mathrm{C}$ in Kłodzko to $10.3{ }^{\circ} \mathrm{C}$ in Zielona Góra (Figure 5c).

Over the study area, on average in June, conditions causing no thermal stress were recorded the most frequently (Figure 7a). They usually occurred in the north of the country, particularly in the north-west and in the lower course of the Vistula River, as well as in the south of the country with an increase in height above sea level. In particular stations, the share of heat stress of this category varied from $60 \%$ in Rzeszów to $79 \%$ in Zakopane. The highest frequency of days with UTCI above $26.0^{\circ} \mathrm{C}$, i.e., moderate, strong, and very strong heat stress, was recorded in the upper course of the Oder River and in central Poland. Its decrease progressed northwards, as well as in areas with higher location. Days with the analysed UTCI values occurred the most seldom in Łeba (5\%), and most frequently in Raciborz (31\%). In June, days with UTCI below $9.0^{\circ} \mathrm{C}$, i.e., slight, moderate, and strong cold stress, were recorded the most seldom. Their highest frequency was observed at the coast; in Łeba, they constituted $28 \%$ of days of the analysed month. In the analysed multi-annual period, in $47 \%$ of stations, an increase in the number of days with UTCI above $26.0{ }^{\circ} \mathrm{C}$ was recorded, and in $36 \%$ of these stations, the changes were statistically significant. In the further $47 \%$ of stations, no changes were recorded, and in $6 \%$ of stations, a statistically non-significant decrease in the analysed days. Days with UTCI below $9.0^{\circ} \mathrm{C}$ occurred increasingly more seldom in $90 \%$ of stations, and in $80 \%$ of the analysed stations, statistically significant changes were determined. In the remaining $10 \%$ of stations, no changes were observed in the frequency of occurrence of the analysed days.
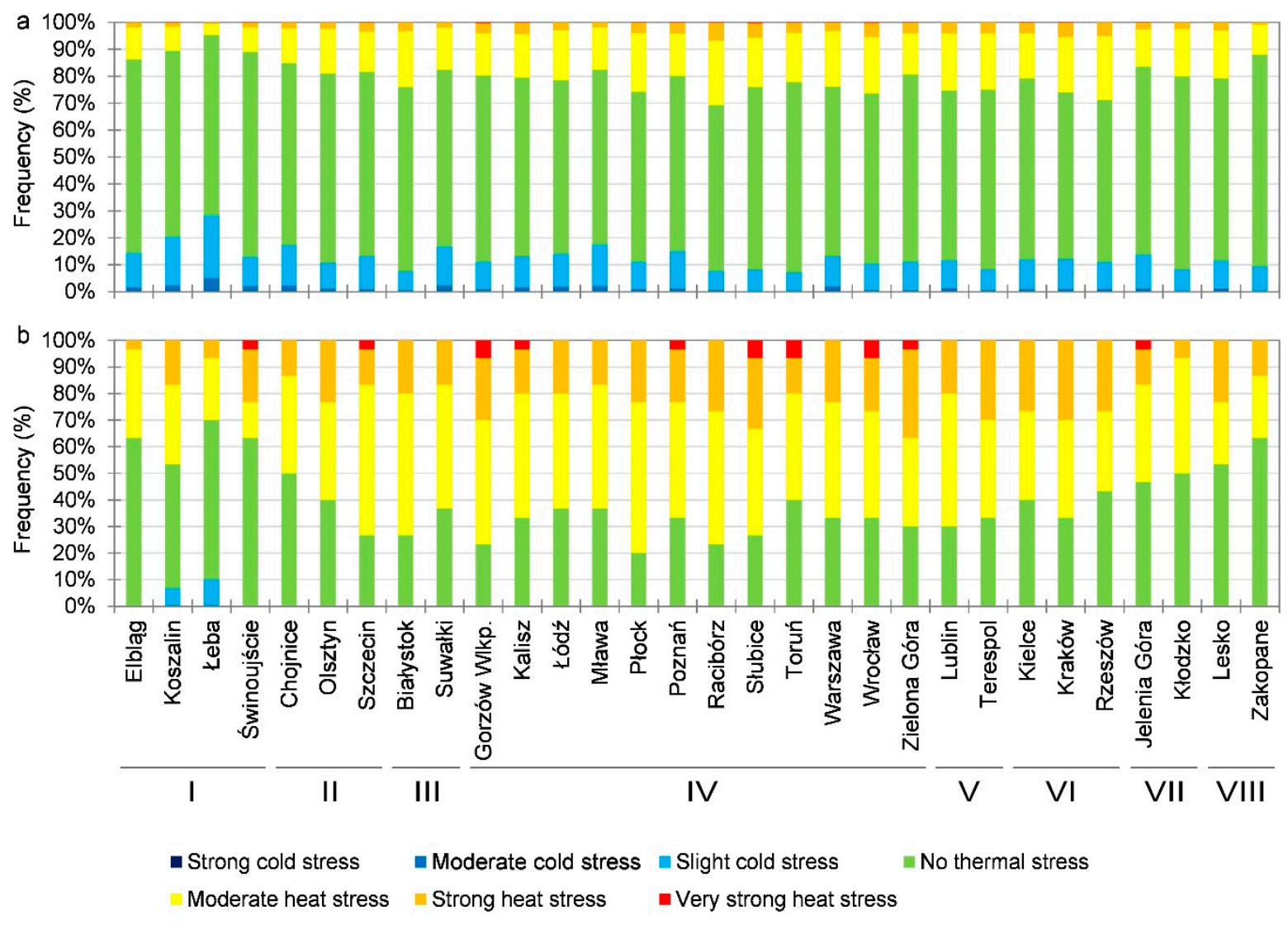

Figure 7. Frequency of occurrence of particular categories of heat stress in June in the years 1966-2019 (a) and 2019 (b).

Conditions in June 2019 were considerably different. Conditions of no thermal stress constituted more than half of all days of the month in only five stations, and half in two stations (Figure $7 \mathrm{~b}$ ). Such days occurred most seldom in the area from central Poland to 
the upper course of the Oder River, and most frequently in the north and south of the country with an increase in height above sea level. In particular stations, the share of days with no thermal heat stress varied from 20\% in Płock to 63\% in Suwałki, Świnoujście, and Zakopane. The greatest differences towards average conditions exceeded $40 \%$, and were recorded in Gorzów Wielkopolski, Płock, Białystok, Szczecin, and Słubice. In a large majority of stations, days with UTCI above $26.0^{\circ} \mathrm{C}$ were recorded the most frequently. In $73 \%$ of stations, they constituted more than half of days of the month. They were the most frequently recorded in the area with the smallest share of days with no thermal stress. The frequency of days with UTCI above $26.0^{\circ} \mathrm{C}$ varied from $30 \%$ in Łeba to $80 \%$ in Płock. In 10 stations (Gorzów Wielkopolski, Słubice, Torun, Wrocław, Jelenia Góra, Kalisz, Poznań, Szczecin, Świnoujście, Zielona Góra), days with very strong heat stress (UTCI above $38.0^{\circ} \mathrm{C}$ ) were recorded. The highest deviations in the frequency of days with UTCI above $26.0^{\circ} \mathrm{C}$ towards average conditions exceeded $50 \%$, and occurred in Gorzów Wielkopolski, Szczecin, Płock, and Zielona Góra. Days with UTCI below $9.0^{\circ} \mathrm{C}$ were only recorded in Łeba and Koszalin.

The monthly course of UTCI points to the occurrence of three periods with evidently high values in June 2019, i.e., from the middle of the first decade, half of the second decade, and the second half of the third decade of the month. In these periods, at least one day in each station was recorded with UTCI above $32.0^{\circ} \mathrm{C}$, i.e., above the threshold of strong heat stress (Figure 8). The longest sequence of such days was recorded in Kraków; it lasted for 6 days (from 10 to 15 June). In Raciborz, Terespol, and Warszawa, the period was one day shorter, and occurred from 11 to 15 June. Moreover, in many stations, 2-4-day-long sequences of such days were recorded. The highest UTCI values above $38.0{ }^{\circ} \mathrm{C}$ were recorded on 26 and 30 June. Both on the former and latter day, this threshold was exceeded in seven stations (Gorzów Wielkopolski, Jelenia Góra, Kalisz, Poznań, Słubice, Szczecin, Świnoujście, Toruń, and Zielona Góra). In four stations (Gorzów Wielkopolski, Łódź, Mława, and Płock), during all days of the month, UTCI was higher than the multi-annual mean. In the remaining stations, days with negative anomalies were recorded, and their number varied from 1 day in Jelenia Góra, Kraków, Słubice, Szczecin, Toruń, Warszawa, and Zielona Góra to 5 days in Elblag and Kłodzko. The highest UTCI anomalies reached $20.0^{\circ} \mathrm{C}$ and more, and were recorded in Łeba $\left(23.5^{\circ} \mathrm{C}\right)$, Jelenia Góra $\left(20.4^{\circ} \mathrm{C}\right)$, Poznań $\left(20.3^{\circ} \mathrm{C}\right)$, and Koszalin $\left(20.0^{\circ} \mathrm{C}\right)$. 

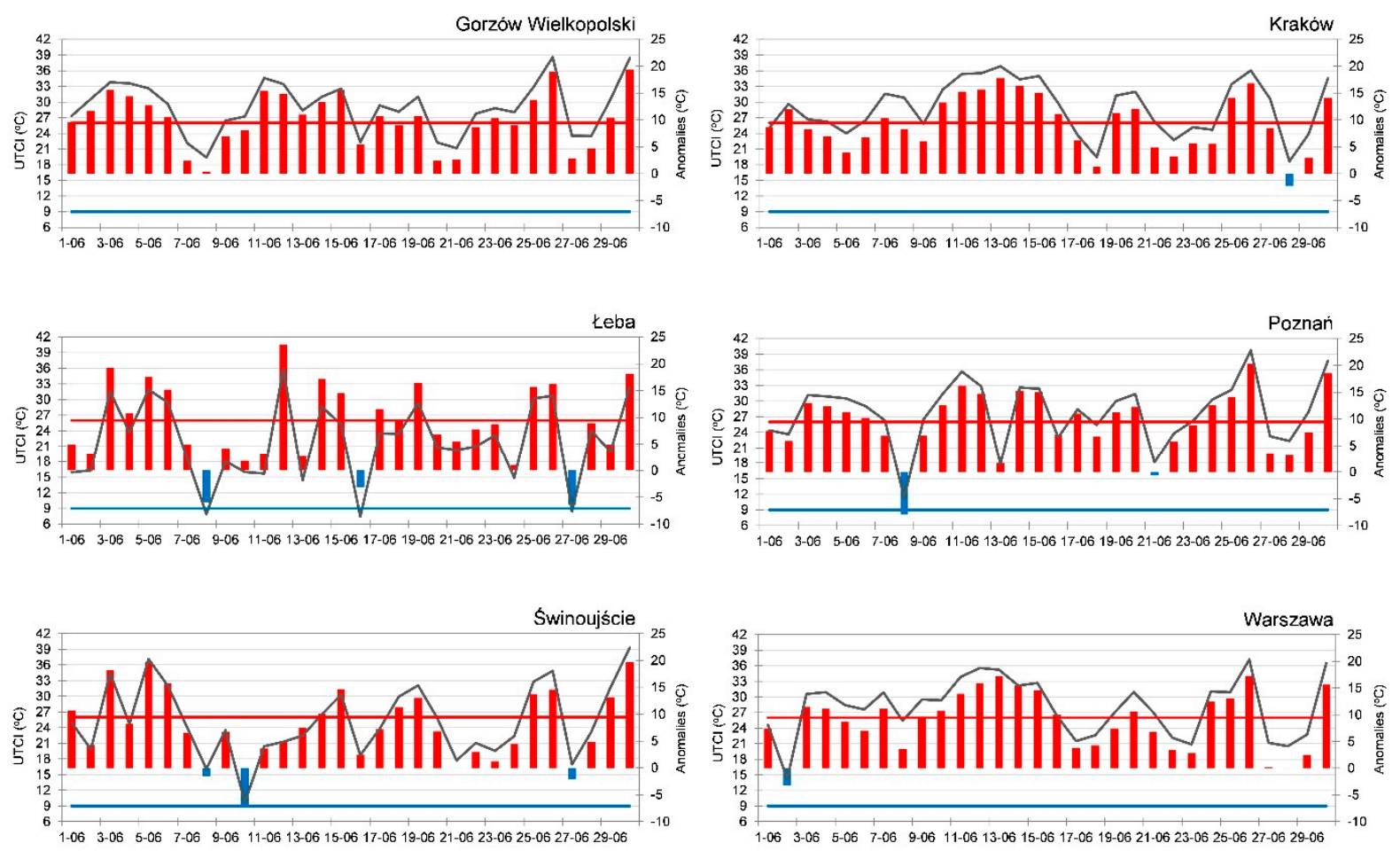

Figure 8. Monthly course of UTCI in June 2019 (line) with anomalies (column). The red line is the heat stress threshold, the blue line is the cold stress threshold.

\subsection{Effect of Atmospheric Circulation}

In June 2019, on average, a high-pressure system with a centre over Lithuania persisted over Europe (>1018 hPa) (Figure 9). Simultaneously, a shallow low-pressure system persisted over the ocean and the British Isles (in the centre $<1013 \mathrm{hPa}$ ). In the analysed month, over the dominant area of central and eastern Europe, SLP was higher than on average in the multi-annual period. The highest anomalies exceeded $4 \mathrm{hPa}$. Over Western Europe and a considerable part of the ocean in that period, SLP was lower by a maximum of more than $3 \mathrm{hPa}$. Such SLP distribution generated advection of air masses from the south-western sector. The air masses were substantially warmer than on average in the multi-annual period, as evidenced by positive T850 anomalies that reached the highest values over central Europe. The presence of warm air masses is also suggested by higher persistence of $500 \mathrm{hPa}$ isobaric surface, persisting over the analysed area more than $100 \mathrm{~m}$ higher than on average. 

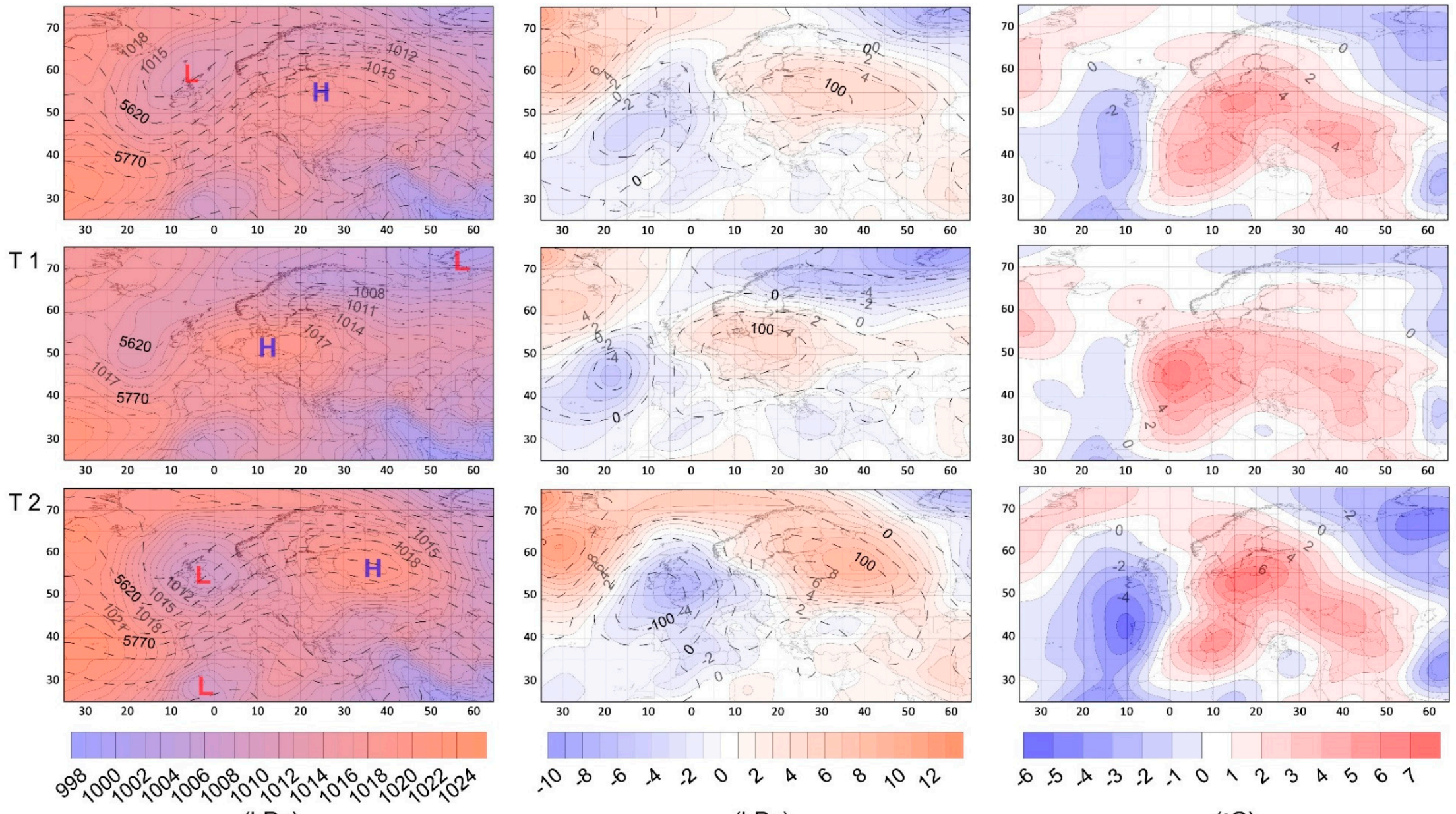

$(\mathrm{hPa})$

\section{$1086 \times 202 \times 6810,2$}

(hPa)
$65 \times 32 \times 0 \wedge 23 \star 561$

$\left({ }^{\circ} \mathrm{C}\right)$

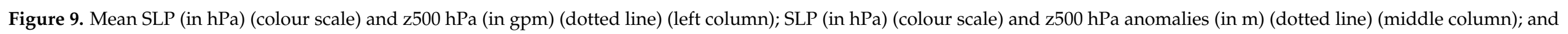
anomalies of T850 (in ${ }^{\circ} \mathrm{C}$ ) (right column) for average conditions and for situations 1 (T1) and 2 (T2) in June 2019. 
The detailed analysis showed the occurrence of two primary baric situations in June 2019 (Figure 9). The first situation (T1) was approximate to average conditions for the entire month and was characterised by the presence of a high over central Europe (in the centre $>1018 \mathrm{hPa}$ ). On these days, SLP over the region was higher than on average in the multi-annual period. The greatest anomalies covered among others the territory of Poland $(>4 \mathrm{hPa})$. Simultaneously, SLP was lower over northern and south-western Europe. In the second situation (T2), two baric systems with latitudinal orientation persisted over Europe, i.e., a low over the western regions $(<1010 \mathrm{hPa})$ and a high over the eastern regions $(>1021 \mathrm{hPa})$. A low also persisted over northern Africa $(<1009 \mathrm{hPa})$. On the analysed days, two areas of anomalies were recorded over the continent, i.e., negative in the west (in the centre of the system $<-5 \mathrm{hPa}$ ) and positive in the east (in the centre of the system $>9 \mathrm{hPa}$ ). A boundary between these areas ran over Poland. The western regions of the country were within the range of negative anomalies, and the area of central and eastern Poland within the range of positive anomalies. The situations described above generated somewhat different advection of air masses. In T1, advection from the west and south-west towards central Europe, including Poland, was dominant. The highest T850 anomalies were recorded over France $\left(>6^{\circ} \mathrm{C}\right)$. In T2, advection from the south was predominant, and the greatest T850 anomalies were observed over the study area $\left(>6^{\circ} \mathrm{C}\right)$. The direction of advection of air masses is suggested by the course of isoanomalies at the $850 \mathrm{hPa}$ level. Next to positive anomalies of air temperature at the isobaric level of $850 \mathrm{hPa}$, also z500 hPa anomalies confirm the presence of warm air masses. Both in T1 and T2, z500 hPa persisted over the study area lower than on average by more than $100 \mathrm{~m}$.

In the following year, the description of circulation conditions employed the Grosswetterlagen circulation calendar based on which each day of the month was ascribed a particular circulation type (Figure 10). In the analysed multi-annual period in June, cyclonic circulation was prevalent (57.5\% of all days) over anticyclonic circulation (41.5\% of all days). The remaining $1 \%$ of days were non-specified situations. The analysis of particular types revealed the dominance of $\mathrm{WZ}(14.6 \%)$. Frequency exceeding $5 \%$ was recorded for types BM (9.1\%), TRW (7.7\%), TRM (6.6\%), HM (6.4\%), and WA (6\%). The most seldom occurrence, with frequency below $1 \%$, concerned types SZ $(0.4 \%)$, SEA $(0.6 \%)$, SEZ (0.7\%), and HNFA $(0.9 \%)$. The study shows that weather conditions in June were primarily shaped by westerly, northerly circulation, and the high persisting over central Europe.

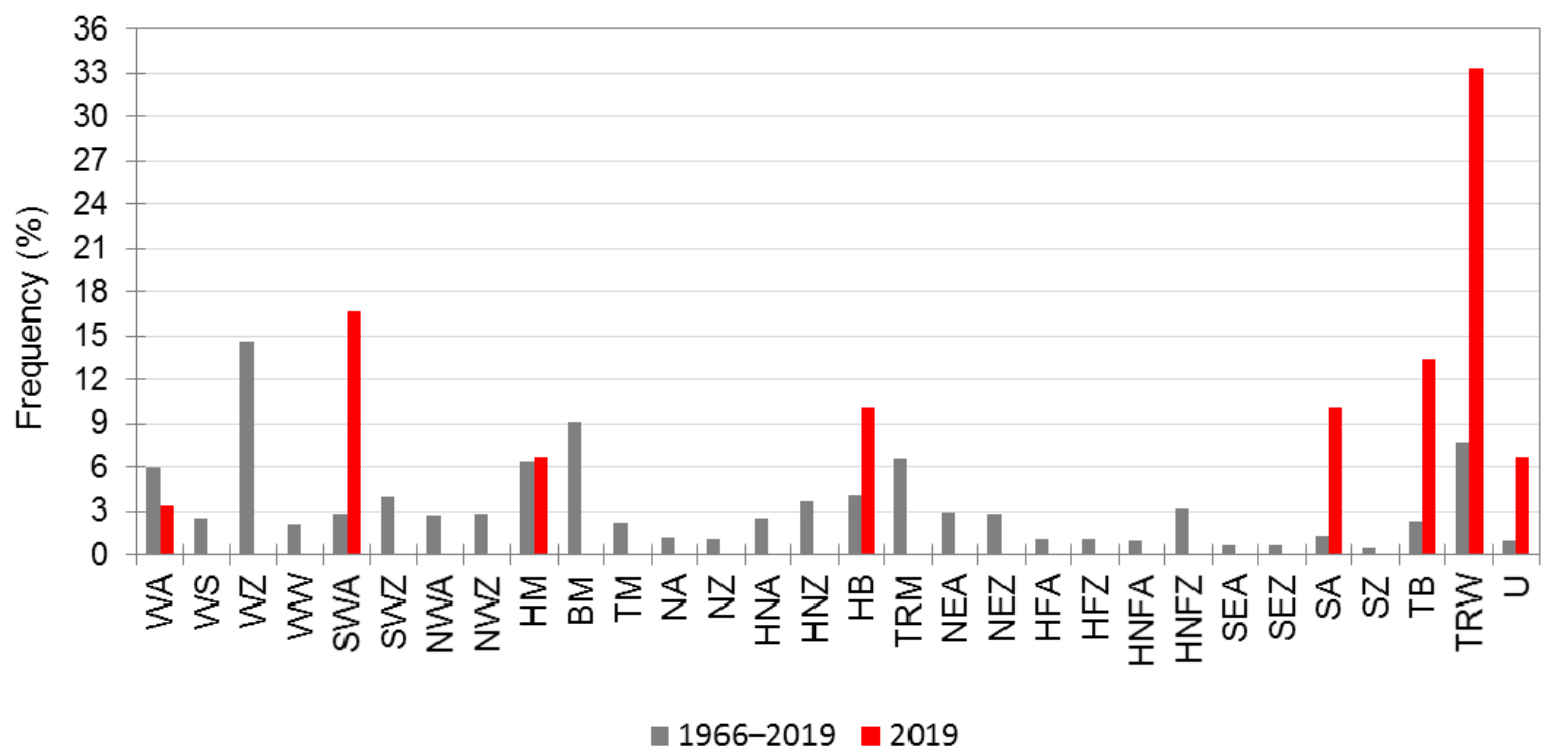

Figure 10. Frequency of occurrence of individual GWL circulation types in June in the years 1966-2019 and 2019.

In June 2019, cyclonic and anticyclonic circulation occurred with approximate frequency (46.7\% each) (Figure 10). Considering particular circulation types, type TRW 
showed evident dominance (33.3\%), whereas, on average, in the analysed multi-annual period, it was the third type in terms of frequency. The second type in terms of frequency was SWA $(16.7 \%)$, followed by types: TB, HB, SA, HM, and WA. In the analysed month, southerly $(56.7 \%)$ and south-westerly circulation $(16.7 \%)$ was predominant.

\section{Discussion and Summary}

The study showed high spatial variability of human-biometeorological conditions in Poland, with strenuous character increasing from the north to the south of the country. The lowest UTCI values were on average recorded at the coast of the Baltic Sea and in the north-eastern regions of the country, and highest in the upper course of the Oder River. Mean UTCI calculated for the entire area in the analysed period varied from $16.5^{\circ} \mathrm{C}$ in 1980 to $24.3^{\circ} \mathrm{C}$ in 2019 . In the analysed multi-annual period, UTCI increased in the summer season, with the highest intensity in north-east Poland.

The consequence of the observed changes was an increase in the frequency of days with heat stress categories (days with UTCI $>26.0^{\circ} \mathrm{C}$ ). The most intensive changes were particularly determined in the eastern and central regions of the country. The aforementioned changes were accompanied by a decrease in the frequency of days with cold stress categories (days with UTCI $<9.0^{\circ} \mathrm{C}$ ). In both cases, in the majority of stations, the changes were statistically significant. The obtained results correspond with earlier research from Poland, pointing to an increase in the frequency of days with strong and very strong heat stress [30,46]. Krzyżewska et al. [46] evidenced that from the beginning of the 21st century, such changes primarily concerned the central, upland, and south-eastern regions, emphasising their potential negative effect on the intensity of tourist traffic in these areas. A similar direction of changes in human-biometeorological conditions was also determined in other regions of Europe [29,47,48].

At the scale of the entire country, the summer season in 2019 stood out in the context of the multi-annual period. As mentioned above, it was a season with the highest mean UTCI value for the entire territory of Poland. A characteristic feature of the season was also more frequent occurrence of days with $\mathrm{UTCI}>26.0^{\circ} \mathrm{C}$, i.e., days with moderate, strong, and very strong heat stress. In that season, the course of mean UTCI in certain months diverted from average conditions in the analysed multi-annual period. The highest mean monthly index value was recorded not in August or July, but in June.

Anomalies in that month exceeded $10.0^{\circ} \mathrm{C}$. Like in the case of the entire summer season, UTCI also increased in June of the analysed period. The increase was statistically significant over the majority of the study area. The comparison of the obtained results with earlier research, covering the second half of the 20th century [49], reveals an evident acceleration of UTCI increase in June and over the entire summer season.

As was already mentioned earlier, in the summer season 2019, the highest mean monthly UTCI values occurred in June. Over the entire area, the values were record high in the analysed multi-annual period for June. In a large majority of stations, days with UTCI above $26.0^{\circ} \mathrm{C}$ were recorded the most frequently. In $73 \%$ of stations, they constituted more than half of days in the month. These results confirm studies by Sulikowska and Wypych [8] as well as Xu et al. [9] that evidenced that more than half of days in the month were hot days in central Europe. The research showed that except for single days, UTCI was higher than average on particular days of the month in the multi-annual period, and in the majority of stations three periods with very high UTCI values could be designated even exceeding the threshold of very strong heat stress. These periods were particularly recorded during heat waves occurring in central Europe [9]. The highest UTCI values in many stations were approximate, or even higher than the maximum index values recorded during the heat wave from 2015 [32]. An increase in the stress of organisms caused by human-biometeorological conditions in the beginning of summer may constitute a threat to human health and life due to the lack of adaptation. As shown by research from the USA, mortality recorded during the first heat wave in a given year was higher than during the subsequent ones due to the lack of adaptation of people to this type of weather conditions 
following cool months [50]. According to Kuchcik [51], an increase in the frequency of extremely hot thermal conditions in the 21st century is accompanied by mitigation of an increase in mortality in comparison to the 1980s and 1990s, suggesting an increase in human adaptation to such conditions.

Weather conditions in June 2019 were primarily shaped by two baric situations. In the first case, a high-pressure system persisted over central Europe. In the second situation, two systems occurred over the continent, i.e., a low in the west and high in the east. Such baric conditions caused advection of air masses from the west and south-west in the first case, and from the south in the second case. Both situations generated inflow of warm air masses, as confirmed by positive anomalies of T850 and z500 hPa. Next to advection of air masses, high pressure weather is accompanied by strong inflow of solar radiation with small or no cloudiness. Similar baric conditions were determined by Sulikowska and Wypych [8]. The authors evidenced that during hot days in June 2019 over central Europe, z500 hPa isohypses were bent northwards, developing an evident elevation over this part of the continent. Moreover, earlier research showed that approximate baric conditions caused the occurrence of strong and very strong heat stress in Poland [30].

Further increase in UTCI and exceedance of further record-breaking values should be expected in the next decades, as shown by simulations in changes in the number of characteristic days. According to Błażejczyk et al. [52], in the years 2000-2100 in Warszawa, an increase in the number of heat stress days will occur at a rate of 0.9 day/10 years. An increase in heat stress in subsequent decades was also pointed out by Miszuk et al. [53] analysing climate-tourist conditions in the Polish-Saxon border area that will be negatively affected by such an increase. A similar direction of changes is forecasted by Matzarakis and Endler [54] in south-western Germany, with an evident increase in the frequency of days with strong heat stress and extreme heat stress (according to PET) by the end of the 21st century. Such days may constitute even approximately $40 \%$ of days in summer in total.

\section{Conclusions}

High spatial and temporal variability of human-biometeorological conditions in Poland has been determined over the study period. The progressing climate changes contributed to an increase in heat stress in the summer season. The recent years showed increasingly more frequent occurrence of months and seasons with very unfavourable human-biometeorological conditions. This is exemplified by atmospheric conditions recorded in June 2019. It was one of months with the most strenuous weather in humanbiometeorological terms in the last decade. The recorded conditions can constitute a particular threat to children as well as elderly and ill persons. Considering the above, such persons should be recommended to reduce time spent outdoors, particularly around noon. Areas most threatened with the occurrence of human-biometeorological conditions causing considerable heat stress of the human in Poland are those within the Oder River valley, particularly in its upper course, and central regions of the country. The occurrence of the described biometeorological conditions was caused by baric conditions resulting in advection of air masses from the southern and western sector. In the analysed month over central Europe, including Poland, considerably warmer air masses persisted than on average in the multi-annual period. In accordance with the Grosswetterlagen classification, frequency considerably higher than the average in the multi-annual period was primarily determined for type TRW, SWA, and TB that generated advection of air masses from the aforementioned sectors. According to that classification, in June 2019, approximate frequency was observed for cyclonic and anticyclonic circulation, which is in line with the designated situations characterised by the same frequency.

Funding: This work was supported by the National Science Centre, Poland (grant number UMO2020/37/B/ST10/00217).

Institutional Review Board Statement: Not applicable.

Informed Consent Statement: Not applicable. 
Data Availability Statement: The obtained data can be made available on request of interested parties under the condition of approval of the request by the authors of the article.

Conflicts of Interest: The author declare no conflict of interest.

\section{References}

1. IPCC. Climate Change 2013: The Physical Science Basis. Contribution of Working Group I to the Fifth Assessment Report of the Intergovernmental Panel on Climate Change; Cambridge University Press: Cambridge, UK; New York, NY, USA, 2013.

2. IPCC. Climate Change 2021: The Physical Science Basis. Contribution of Working Group I to the Sixth Assessment Report of the Intergovernmental Panel on Climate Change; Cambridge University Press: Cambridge, UK, 2021.

3. NOAA. 2020. Available online: https://www.ncdc.noaa.gov/sotc/global/201713 (accessed on 4 May 2021).

4. Hoy, A.; Hänsel, S.; Maugeri, M. An endless summer: 2018 heat episodes in Europe in the context of secular temperature variability and change. Int. J. Climatol. 2020, 40, 6315-6336. [CrossRef]

5. Tomczyk, A.M.; Bednorz, E. The extreme year-Analysis of thermal conditions in Poland in 2018. Theor. Appl. Climatol. 2020, 139, 251-260. [CrossRef]

6. Zahradníček, P.; Brázdil, R.; Štěpánek, P.; Trnka, M. Reflections of global warming in trends of temperature characteristics in the Czech Republic, 1961-2019. Int. J. Climatol. 2021, 41, 1211-1229. [CrossRef]

7. Van Oldenborgh, G.J.; Philip, S.; Kew, S.; Vautard, R.; Boucher, O.; Otto, F.; Haustein, K.; Soubeyroux, J.M.; Ribes, A.; Robin, Y.; et al. Human Contribution to the Record-Breaking June 2019 Heat Wave in France; World Weather Attribution (WWA): Amsterdam, The Netherlands, 2019.

8. Sulikowska, A.; Wypych, A. How Unusual Were June 2019 Temperatures in the Context of European Climatology? Atmosphere 2020, 11, 697. [CrossRef]

9. Xu, P.; Wang, L.; Liu, Y.; Chen, W.; Huang, P. The record-breaking heat wave of June 2019 in Central Europe. Atmos. Sci. Lett. 2020, 21, e964. [CrossRef]

10. Ma, F.; Yuan, X.; Jiao, Y.; Ji, P. Unprecedented Europe Heat in June-July 2019: Risk in the Historical and Future Context. Geophys. Res. Lett. 2020, 47, L087809. [CrossRef]

11. Matzarakis, A.; Muthers, S.; Graw, K. Thermische Belastung von Bewohnern in Städten bei Hitzewellen am Beispiel von Freiburg (Breisgau). Bundesgesundheitsblatt-Gesundheitsforschung-Gesundheitsschutz 2020, 63, 1004-1012. [CrossRef]

12. Michelozzi, P.; de Donato, F.; Accetta, G.; Forastiere, F.; D'Ovidio, M.; Perucci, C.; Kalkstein, L.S. Impact of heat waves on mortality-Rome, Italy June-August 2003. Morb. Mortal. Wkly. Rep. 2004, 53, 369-371.

13. Vandentorren, S.; Suzan, R.; Medina, S.; Pascal, M.; Maulpoix, A.; Cohen, J.C.; Ledrans, M. Mortality in 13 French Cities during the August 2003 Heat Wave. Am. J. Public Health 2004, 94, 1518-1520. [CrossRef] [PubMed]

14. Rebetez, M.; Dupont, O.; Giroud, M. An analysis of the July 2006 heatwave extent in Europe compared to the record year of 2003. Theor. Appl. Climatol. 2006, 95, 1-7. [CrossRef]

15. Muthers, S.; Laschewski, L.; Matzarakis, A. The Summers 2003 and 2015 in South-West Germany: Heat Waves and Heat-Related Mortality in the Context of Climate Change. Atmosphere 2017, 8, 224. [CrossRef]

16. Grumm, R.H. The Central European and Russian heat event of July-August 2010. Bull. Am. Meteorol. Soc. 2011, 92, 1285-1296. [CrossRef]

17. Otto, F.E.L.; Massey, N.; Van Oldenborgh, G.J.; Jones, R.G.; Allan, M.R. Reconciling two approaches to attribution of the 2010 Russian heat wave. Geophys. Res. Lett. 2012, 39, L04702. [CrossRef]

18. Hoy, A.; Hänsel, S.; Skalak, P.; Ustrnul, Z.; Bochníček, O. The extreme European summer of 2015 in a long-term perspective. Int. J. Climatol. 2017, 37, 943-962. [CrossRef]

19. Krzyżewska, A.; Dyer, J. The August 2015 mega-heatwave in Poland in the context of past events. Weather 2018, 73, 207-214. [CrossRef]

20. Tomczyk, A.M.; Bednorz, E. Heat waves in Central Europe and tropospheric anomalies of temperature and geopotential heights. Int. J. Climatol. 2019, 39, 4189-4205. [CrossRef]

21. Robine, J.M.; Cheung, S.L.; Le Roy, S.; Van Oyen, H.; Herrmann, F.R. Report on Excess Mortality in Europe during Summer 2003. EU Community Action Programme for Public Health; European Commission: Brussels, Belgium, 2007.

22. Matzarakis, A.; Mayer, H.; Iziomon, M.G. Applications of a universal thermal index: Physiological Equivalent Temperature. Int. J. Biometeorol. 1999, 43, 76-84. [CrossRef]

23. Matzarakis, A.; Rutz, F.; Mayer, H. Modelling radiation fluxes in simple and complex environment-Application of the RayMan model. Int. J. Biometeorol. 2007, 51, 323-334. [CrossRef]

24. Błażejczyk, K.; Bröde, P.; Fiala, D.; Havenith, G.; Holmér, I.; Jendritzky, G.; Kampmann, B. UTCI-New index for assessment of heat stress in man. Przeglad Geogr. 2010, 82, 49-71. (In Polish)

25. Błażejczyk, K.; Epstein, Y.; Jendritzky, G.; Staiger, H.; Tinz, B. Comparison of UTCI to selected thermal indices. Int. J. Biometeorol. 2012, 56, 515-535. [CrossRef]

26. Kolendowicz, L.; Półrolniczak, M.; Szyga-Pluta, K.; Bednorz, E. Human-biometeorological conditions in the southern Baltic coast based on the universal thermal climate index (UTCI). Theor. Appl. Climatol. 2018, 134, 363-379. [CrossRef]

27. Matzarakis, A.; Fröhlich, D.; Bermon, S.; Adami, P.E. Quantifying Thermal Stress for Sport Events-The Case of the Olympic Games 2020 in Tokyo. Atmosphere 2018, 9, 479. [CrossRef] 
28. Roshan, G.H.R.; Ghanghermeh, A.A.; Kong, Q. Spatial and temporal analysis of outdoor human thermal comfort during heat and cold waves in Iran. Weather Clim. Extrem. 2018, 19, 58-67. [CrossRef]

29. Pecelj, M.M.; Lukić, M.Z.; Filipović, D.J.; Protić, B.M.; Bogdanović, U.M. Analysis of the Universal Thermal Climate Index during heat waves in Serbia. Nat. Hazards Earth Syst. Sci. 2020, 20, 2021-2036. [CrossRef]

30. Tomczyk, A.M.; Owczarek, M. Occurence of strong and very strong heat stress in Poland and its circulation conditions. Theor. Appl. Climatol. 2020, 139, 893-905. [CrossRef]

31. Bröde, P.; Krüger, E.L.; Fiala, D. UTCI: Validation and practical application to the assessment of urban outdoor thermal comfort. Geogr. Pol. 2013, 86, 11-20. [CrossRef]

32. Krzyżewska, A.; Wereski, S.; Demczuk, P. Biometeorological conditions during an extreme heatwave event in Poland in August 2015. Weather 2019, 75, 183-189. [CrossRef]

33. Tomczyk, A.M.; Bednorz, E.; Matzarakis, A. Human-biometeorological conditions during heat waves in Poland. Int. J. Climatol. 2020, 40, 5043-5055. [CrossRef]

34. Wibig, J. Heat waves in Poland in the period 1951-2015: Trends, patterns and driving factors. Meteorol. Hydrol. Water Manag. 2018, 6, 37-45. [CrossRef]

35. Tomczyk, A.M.; Bednorz, E.; Półrolniczak, M.; Kolendowicz, L. Strong heat and cold waves in Poland in relation with the large-scale atmospheric circulation. Theor. Appl. Climatol. 2019, 137, 1909-1923. [CrossRef]

36. Kuchcik, M. Mortality and thermal environment (UTCI) in Poland-Long-term, multi-city study. Int. J. Biometeorol. 2020, 65, 1529-1541. [CrossRef] [PubMed]

37. Błażejczyk, K. Bioklimatyczne uwarunkowania rekreacji i turystyki w Polsce. Pr. Geogr. 2004, 192.

38. Bröde, P.; Fiala, D.; Błażejczyk, K.; Holmer, I.; Jendritzky, G.; Kampmann, B.; Tinz, B.; Havenith, G. Deriving the operational procedure for the Universal Thermal Climate Index (UTCI). Int. J. Biometeorol. 2012, 56, 481-494. [CrossRef]

39. Fiala, D.; Lomas, K.J.; Stohrer, M. A computer model of human thermoregulation for a wide range of environmental conditions: The passive system. J. Appl. Physiol. 1999, 87, 1957-1972. [CrossRef] [PubMed]

40. Fiala, D.; Lomas, K.J.; Stohrer, M. Computer prediction of human thermoregulatory and temperature responses to a wide range of environmental conditions. Int. J. Biometeorol. 2001, 45, 143-159. [CrossRef]

41. Błażejczyk, K.; Błażejczyk, M. BioKlima; Verion 2.6; Polish Academy of Sciences: Warszawa, Poland, 2006; Available online: www.igipz.pan.pl/bioklima.html (accessed on 5 May 2020).

42. Błażejczyk, K.; Jendritzky, G.; Bröde, P.; Fiala, D.; Havenith, G.; Epstein, Y.; Psikuta, A.; Kampmann, B. An introduction to the Universal Thermal Climate Index (UTCI). Geogr. Pol. 2013, 86, 5-10. [CrossRef]

43. Ward, J.H. Hierarchical grouping to optimize an objective function. J. Am. Stat. Assoc. 1963, 58, 236-244. [CrossRef]

44. Kalnay, E.; Kanamistu, M.; Kistler, R.; Collins, W.; Deaven, D.; Gandin, L.; Iredell, M.; Saha, S.; White, G.; Woollen, J.; et al. The NMC/NCAR 40-Year Reanalysis Project. Bull. Am. Meteorol. Soc. 1996, 77, 437-471. [CrossRef]

45. Werner, P.C.; Gerstengarbe, F.W. Katalog der Großwetterlagen Europas (1881-2009) nach Paul Hess und Helmut Brezowsky; PIK Report 119; Potsdam Institute for Climate Change Impact Research: Potsdam, Germany, 2010.

46. Krzyżewska, A.; Wereski, S.; Dobek, M. Summer UTCI variability in Poland in the twenty-first century. Int. J. Biometeorol. 2020, 65, 1497-1513. [CrossRef]

47. Di Napoli, C.; Pappenberger, F.; Cloke, H.L. Assessing heat-related health risk in Europe via the Universal Thermal Climate Index (UTCI). Int. J. Biometeorol. 2018, 62, 1155-1165. [CrossRef]

48. Shevchenko, O.; Snizhko, S.; Matzarakis, A. Recent trends on human thermal bioclimate conditions in Kyiv, Ukraine. Geogr. Pol. 2020, 93, 89-106. [CrossRef]

49. Okoniewska, M.; Więcław, M. Long term variability of bioclimate conditions in the second half of the 20 century based on Universal Thermal Climate Index. J. Health Sci. 2013, 3, 116-129. (In Polish)

50. Anderson, G.B.; Bell, M.L. Heat waves in the United States: Mortality risk during heat waves and effect modification by heat wave characteristics in 43 U.S. communities. Environ. Health Perspect. 2011, 119, 210-218. [CrossRef] [PubMed]

51. Kuchcik, M. Thermal conditions in Poland at the turn of the 20th and 21st centuries, and their impact on mortality. Geogr. Stud. 2017, 263. Available online: https://rcin.org.pl/igipz/dlibra/publication/85081?tab=1\&language=en (accessed on 28 August 2021).

52. Błażejczyk, K.; Idzikowska, D.; Błażejczyk, A. Forecast changes for heat and cold stress in Warsaw in the 21st century, and their possible influence on mortality risk. Pap. Glob. Chang. 2013, 20, 47-62. [CrossRef]

53. Miszuk, B.; Otop, I.; Strońska, M.; Schwarzak, S.; Surke, M. Tourism-climate conditions and their future development in the Polish-Saxon border area. Meteorol. Z. 2016, 25, 421-434. [CrossRef]

54. Matzarakis, A.; Endler, C. Climate change and thermal bioclimate in cities: Impacts and options for adaptation in Freiburg, Germany. Int. J. Biometeorol. 2010, 54, 479-483. [CrossRef] 